Bulletin of Pharmaceutical Sciences
Assiut University

\title{
PHYTOCHEMICAL INVESTIGATION OF THE AERIAL PARTS OF CENTAURIUM SPICATUM WITH HEPATOPROTECTIVE AND mRNA ENZYMATIC INHIBITION ACTIVITIES
}

\author{
Ahmed E. Allam ${ }^{1 *}$, Mohamed A. El-Shanawany ${ }^{2}$, Enaam Y. Backheet ${ }^{2}$ and Alaa M. Nafady ${ }^{1}$ \\ ${ }^{1}$ Department of Pharmacognosy, Faculty of Pharmacy, Al-Azhar University, Assiut 71524, \\ Egypt \\ ${ }^{2}$ Department of Pharmacognosy, Faculty of Pharmacy, Assiut University, Assiut 71526, Egypt
}

\begin{abstract}
Five compounds (1-5) were firstly reported from the genus Centaurium family Gentianaceae. They were identified as Lisianthoside 1, Secoxyloganin 2, Secologanin dimethyl acetal 3, 1,8-Dihydroxy-3,5,6,7-tetramethoxyxanthone (Demethyleustomin) 4 and 1-Hydroxy3,5,6,7,8-pentamethoxyxanthone (Eustomin) 5. Structure elucidation was carried out with support of chemical and spectral analysis including $1 D$ and $2 D N M R$ experiments. All the isolated compounds showed promising antioxidant activity, liver microsomal enzymes reducing activity and CYP3A4 mRNA inhibition activity in the HepG2 cell line.
\end{abstract}

\section{INTRODUCTION}

Centaurium spicatum (L.) Fritsch (Gentianaceae) is an annual herb occurring in Southern Europe and Northern Africa where it is used together with other Centaurium species such as $C$. pulchellum in traditional medicine for treatment of abdominal pain, hypertension, gallstones, kidney and ureter stones, renal colic, wounds and diabetes ${ }^{1 \& 2}$. A survey of the current literatures revealed the isolation and identification of secoiridoids (sweroside, swertiamarin and gentiopicrin) and polyoxygenated xanthones from the plant ${ }^{3 \& 4}$. Alkaloids of pyridine type (e.g. gentianine), spicatine and the series of amides derived from the secoiridoid glucoside swertiamarin and kantaurin were also shown to be present ${ }^{3}$. Among the most important pharmacological activities of the genus Centaury were the hepatoprotective and the antioxidant activities attributed to secoiridoides and flavonoid glycosides $^{5}$. The hepatoprotective and CYP 450 enzymatic activities of the isolated compounds were evaluated in this paper.

Received in 24/6/2014 \& Accepted in 3/12/2014

*Corresponding author: Ahmed E. Allam, E-mail: aallam81@yahoo.co.uk

\section{EXPERIMENTAL}

General experimental procedures

${ }^{1} \mathrm{H}-\mathrm{NMR}(400 \mathrm{MHz})$ and ${ }^{13} \mathrm{C}-\mathrm{NMR}(100$ $\mathrm{MHz}$ ) spectra were measured on a JEOL GSX400 spectrometer in $\mathrm{CD}_{3} \mathrm{OD}$ and DMSO$d_{6}$. Reversed-phase high-performance chromatography experiments were undertaken on ODS columns (particle size: $5 \mu \mathrm{m}$, TOSO, $18 \times 250 \mathrm{~mm}) \mathrm{RP}-23(5 \mu \mathrm{m}$; Waters). Diaion HP-20 (Mitsubishi) (Tokyo, Japan), silica gel (63-210 $\mu \mathrm{m}$; Kanto Kagaku) and ODS (63-212 $\mu \mathrm{m}$; Wako Pure Chemical) (Tokyo, Japan) were used for open column chromatography. Thin-layer chromatography (TLC) was carried out on silica gel $\left(\mathrm{SiO}_{2}, 60-100\right.$ mesh; Wako Pure Chemical) $60 \quad \mathrm{~F}_{254}$ and RP-18 $\quad \mathrm{F}_{254 \mathrm{~S}}$ (Merck). Structural assignments were based on spectra resulting from one or more of the NMR experiments; ${ }^{1} \mathrm{H},{ }^{13} \mathrm{C},{ }^{1} \mathrm{H}-{ }^{1} \mathrm{H}$ COSY, HMQC and HMBC. The Fast Atom Bombardment (FABMS) spectra were carried out on a JEOL JMS SX-102 Mass spectrometer. Optical rotations were measured on (Horiba SEPA3000 high-sensitivity polarimeter. 


\section{Plant material}

C. spicatum (L.) Fritsch (Gentianaceae) aerial parts were collected in May 2009 from New Valley, $200 \mathrm{~km}$ Southwest of Assiut City, Egypt. The plant was identified and authenticated by Prof. Dr. A. Fayed, Professor of Plant Taxonomy, Faculty of Science, Assiut University.

\section{Extraction and isolation}

Air-dried C. spicatum aerial parts $(2 \mathrm{~kg})$ were extracted thrice with $\mathrm{MeOH}(5 \mathrm{~L}$ each) at room temperature. The extracts were combined and filtered through filter paper (Advantec MFS Incorporated). The extracts were removed under reduced pressure using rotary evaporator at $40^{\circ} \mathrm{C}$ to yield the methanol extract $(550 \mathrm{mg})$ which was mixed with distilled water and partitioned between chloroform, ethyl acetate and $n$-butanol ( $1 \mathrm{~L}$ each) to give the chloroform fraction (163 g), ethyl acetate fraction (80 g), $n$-butanol fraction (100 g) and the rest aqueous fraction $(200 \mathrm{~g})$. The ethyl acetate fraction was in turn partitioned between (methanol-water $90 \%$ ) and $n$-hexane to give $90 \%$ methanol fraction $(50 \mathrm{~g})$ and $n$-hexane fraction $(20 \mathrm{~g})$. All fractions were screened for the antioxidant, hepatoprotective and $m$ RNA enzymatic inhibition activities where noticed that the $n$ butanol fraction (100 g) is the most active fraction and hence, it was sub- fractionated on Diaion HP-20 column using water $(2 \mathrm{~L})$ and methanol $(25 \%, 50 \%, 75 \%$ and $100 \%)(2 \mathrm{~L}$ each). The fraction eluted by $50 \%$ methanol from the $n$-butanol fraction) (33.4 g) was further partitioned by chromatography on ODS column $(80 \times 200 \mathrm{~mm}) \quad\left(\right.$ Cosmosil $140 \quad \mathrm{C}_{18}$ PREP, Nacalai Tesque, Tokyo, Japan) using mobile phase systems of $\mathrm{CH}_{3} \mathrm{CN}-\mathrm{H}_{2} \mathrm{O}(10,25$, 40, 50, 70 and $90 \%$ v/v; elution volume: $1.5 \mathrm{~L}$ of each) to give six corresponding fractions. The fraction eluted with $40 \% \mathrm{CH}_{3} \mathrm{CN}$ (3.8 g) was further chromatographed by column chromatography on silica gel and eluted stepwise gradient with $\mathrm{CHCl}_{3}-\mathrm{MeOH}$ (ratios of $9: 1,6: 1,4: 1,3: 1$ and $1: 1, \mathrm{v} / \mathrm{v}$ elution volume: $200 \mathrm{ml}$ each) to give five corresponding fractions. The fraction eluted with 6:1 $\mathrm{CHCl}_{3}-\mathrm{MeOH}$ was further partitioned by preparative HPLC, ODS column: C30 UG-5 ODS $(20 \mathrm{~mm} \times 250 \mathrm{~mm}$ ) particle size: $5 \mu \mathrm{m}$, flow rate: $6 \mathrm{ml} / \mathrm{min}$. (Develosil, Nacalai Tesque, Tokyo, Japan) equipped with a UV detector $(210 \mathrm{~nm})$. The mobile phase was $20 \%$ $\mathrm{CH}_{3} \mathrm{CN}$ in $\mathrm{H}_{2} \mathrm{O}$. This resulted in the isolation of compounds 1-4. These preparative HPLC conditions were also used after gradually increasing the mobile phase to $50 \% \mathrm{CH}_{3} \mathrm{CN}$ in $\mathrm{H}_{2} \mathrm{O}$ to separate the same fraction giving compound $\mathbf{5}$.

\section{Cytotoxic assay (MTT assay)}

This method is a colorimetric assay for assessing cell viability ${ }^{6}$. To determine the cytotoxic activity of the tested samples, THP-1 cells $(180 \mu \mathrm{l})$ were seeded in 96-well plates at $1.0 \times 10^{5}$ cells per well with tested samples (purity > 93\%) (20 $\mu \mathrm{l}$ in DMSO/ PBS) at various concentrations. After 48 -h cultivation, the supernatants were removed, non-adherent cells (THP-1) incubated with the tetrazolium dye; 3-(4,5-dimethylthiazol-2-yl)-2,5-diphenyltetrazolium bromide (MTT), $10 \mu \mathrm{l}, 5 \mathrm{mg} / \mathrm{mL}$ in PBS for $4 \mathrm{~h}$ and then solubilized with $10 \%$ (w/v) sodium dodecyl sulfate (SDS; in $60 \%$ [v/v] dimethyl formamide) solution (100 $\mu \mathrm{l})$ for $18 \mathrm{~h}$. The absorbance was measured at $570 \mathrm{~nm}$ using a microplate reader and the cytotoxicity calculated by comparing absorbance with that of the non-treated control culture. Cell growth curve was graphed using statistical analysis software (Kaleida Graph version 4.00; Synergy Software) and $\mathrm{IC}_{50}$ values calculated using simple linear regression.

\section{DPPH radical scavenging activity}

DPPH assay was performed by a method previously reported by Kumar et $a l^{7}$. The tested samples $(100 \mu \mathrm{l})$ at different concentrations in $\mathrm{MeOH}$ and $1.0 \times 10^{-4} \mathrm{M} \mathrm{DPPH}$ (Wako) (Tokyo, Japan) in $\mathrm{MeOH}(300 \mu l)$ were added to 96-well microtiter plate. The plate was shaken for $1 \mathrm{~min}$ on a plate shaker and incubated for $30 \mathrm{~min}$ at room temperature in the dark. After incubation, the absorbance was recorded at $517 \mathrm{~nm}^{8-10}$. The tested samples at different concentrations without DPPH solution were used as a blank control to eliminate the influence of sample color. Ascorbic acid was used as a positive control ${ }^{7}$ and DPPH solution in $\mathrm{MeOH}$ served as a negative control.

\section{Data analysis}

Ratio (percentage of control) of DPPH was determined as mean \pm SD. Statistical significance was determined by Dunnett's 
multiple test after one-way analysis of variance (ANOVA) with comparison to a control group using statistical analysis software (Kaleida Graph ver. 4.00). Differences were considered significant at $\mathrm{p}<0.05$.

\section{RESULTS AND DISCUSSION}

\section{Results}

Compound 1: Obtained as white amorphous powder $(12 \mathrm{mg}),[\alpha]_{\mathrm{D}}^{31.8}-412^{\circ} \quad(\mathrm{c}=0.333$, $\mathrm{MeOH}) . \quad{ }^{1} \mathrm{H}-,{ }^{13} \mathrm{C}-\mathrm{NMR} \quad(400,100 \mathrm{MHz}$, $\mathrm{CD}_{3} \mathrm{OD}$ ): (Tables 1 and 2). FAB $\mathrm{MS}$ at $\mathrm{m} / \mathrm{z}$ : $717[\mathrm{M}+\mathrm{H}]^{+} \mathrm{C}_{32} \mathrm{H}_{44} \mathrm{O}_{18}$.

Compound 2: Obtained as white crystals (17 mg), m.p. $142-144{ }^{\circ} \mathrm{C} .{ }^{1} \mathrm{H}-,{ }^{13} \mathrm{C}-\mathrm{NMR}$ (400, 100 $\mathrm{MHz}, \mathrm{CD}_{3} \mathrm{OD}$ ): (Tables 1 and 2). FAB MS at $m / z: 405[\mathrm{M}+\mathrm{H}]^{+} \mathrm{C}_{17} \mathrm{H}_{24} \mathrm{O}_{11}$.

Compound 3: Obtained as white amorphous powder $(12 \mathrm{mg}),[\alpha]_{\mathrm{D}}^{28.0}-102.7^{\circ} \quad(\mathrm{c}=0.45$, $\mathrm{MeOH}) .{ }^{1} \mathrm{H}-,{ }^{13} \mathrm{C}-\mathrm{NMR} \quad(400,100 \mathrm{MHz}$,
$\mathrm{CD}_{3} \mathrm{OD}$ ): (Tables 1 and 2). FAB $\mathrm{MS}$ at $m / z$ : $433[\mathrm{M}-\mathrm{H}]^{-} \mathrm{C}_{19} \mathrm{H}_{30} \mathrm{O}_{11}$.

Compound 4: Obtained as pale yellow needles (7 mg), m.p. $220-221{ }^{\circ} \mathrm{C} .{ }^{1} \mathrm{H}-\mathrm{NMR}$ (400 MHz, DMSO- $\left.d_{6}\right): \delta_{\mathrm{H}} 11.95(1 \mathrm{H}, \quad \mathrm{s}, 1-\mathrm{OH})$ and 11.87(1H, s, 8-OH), $6.48(1 \mathrm{H}, \mathrm{d}, J=2.4 \mathrm{~Hz}, \mathrm{H}-$ 4), $6.33(1 \mathrm{H}, \mathrm{d}, J=2.4 \mathrm{~Hz}, \mathrm{H}-2), 4.12(3 \mathrm{H}, \mathrm{s}, 7-$ $\left.\mathrm{OCH}_{3}\right), 3.92\left(3 \mathrm{H}, \mathrm{s}, 6-\mathrm{OCH}_{3}\right), 3.91(3 \mathrm{H}, \mathrm{s}, 3-$ $\left.\mathrm{OCH}_{3}\right)$ and $3.88\left(3 \mathrm{H}, \mathrm{s}, 5-\mathrm{OCH}_{3}\right) .{ }^{13} \mathrm{C}-\mathrm{NMR}$ (100 MHz, DMSO- $d_{6}$ ): Table 2. FAB MS at $m / z: 349[\mathrm{M}+\mathrm{H}]^{+} \mathrm{C}_{17} \mathrm{H}_{16} \mathrm{O}_{8}$.

Compound 5: Obtained as pale yellow needles (6 mg), m.p. 83-84.5 ${ }^{\circ}$ C. ${ }^{1} \mathrm{H}-\mathrm{NMR}$ (400 MHz, DMSO- $\left.d_{6}\right): \delta_{\mathrm{H}} 11.78(1 \mathrm{H}, \mathrm{s}, 1-\mathrm{OH}), \delta_{\mathrm{H}} 6.69$ $(1 \mathrm{H}, \mathrm{d}, J=2.4 \mathrm{~Hz}, \mathrm{H}-4), 6.40(1 \mathrm{H}, \mathrm{d}, J=2.4 \mathrm{~Hz}$, $\mathrm{H}-2), 4.06\left(3 \mathrm{H}, \mathrm{s}, 8-\mathrm{OCH}_{3}\right), 3.89(3 \mathrm{H}, \mathrm{s}, 6-$ $\left.\mathrm{OCH}_{3}\right), 3.86\left(3 \mathrm{H}, \mathrm{s}, 3-\mathrm{OCH}_{3}\right), 3.81(3 \mathrm{H}, \mathrm{s}, 7-$ $\left.\mathrm{OCH}_{3}\right)$ and $3.80\left(3 \mathrm{H}, \mathrm{s}, 5-\mathrm{OCH}_{3}\right) .{ }^{13} \mathrm{C}-\mathrm{NMR}$ (100 MHz, DMSO- $\left.d_{6}\right)$ : Table 2. FAB MS at $m / z: 363[\mathrm{M}+\mathrm{H}]^{+} \mathrm{C}_{18} \mathrm{H}_{18} \mathrm{O}_{8}$.

Table 1: ${ }^{1} \mathrm{H}-\mathrm{NMR}$ assignments for compounds 1-3 $\left(\mathrm{CD}_{3} \mathrm{OD}, 400 \mathrm{MHz}\right)$.

\begin{tabular}{|c|c|c|c|c|}
\hline Proton No. & Cpd. 1 (part a) & Cpd. 1 (part b) & Cpd. 2 & Cpd. 3 \\
\hline 1 & $5.32,2 \mathrm{H}$, br.s & $5.32,2 \mathrm{H}$, br.s & $5.43, \mathrm{~d}, 4.1$ & $5.52, \mathrm{t}, 5.0$ \\
\hline 2 & - & - & - & - \\
\hline 3 & 7.50, br.s & 7.20 , br.s & 7.59, brs & $7.44, \mathrm{~d}, 3.2$ \\
\hline 4 & - & - & - & - \\
\hline 5 & $3.09, \mathrm{~m}$ & $3.26, \mathrm{~m}$ & $3.81, \mathrm{~m}$ & $\begin{array}{l}2.93, \text { ddd, } 7.3, \\
6.8,5.5\end{array}$ \\
\hline 6 & $\begin{array}{l}3.08, \mathrm{~m} \\
2.17, \mathrm{~m}\end{array}$ & $\begin{array}{l}1.61, \mathrm{~m} \\
1.98, \mathrm{~m}\end{array}$ & $\begin{array}{l}\alpha: 2.20, \mathrm{dd}, 16.8,9.6 \\
\beta: 3.03, \mathrm{dd}, 16.8,4.4\end{array}$ & $\begin{array}{l}1.64, \text { ddd, } \\
14.1,7.8,4.1\end{array}$ \\
\hline 7 & $\begin{array}{l}2.8,2 \mathrm{H}, \mathrm{t}, 12.0 \\
4.52, \mathrm{~d}, 12.0\end{array}$ & $\begin{array}{l}4.28,2 \mathrm{H}, \mathrm{t}, 12.0 \\
4.36, \mathrm{~d}, 12.0\end{array}$ & - & $\begin{array}{l}\text { 4.50, dd, } 7.3 \text {, } \\
4.1\end{array}$ \\
\hline 8 & $5.47, \mathrm{dd}, 9.2,18.0$ & $5.55, \mathrm{dd}, 9.9,18.0$ & $\begin{array}{l}5.62, \text { ddd, } 9.2 \text { (cis, H-8, H- } \\
\left.10_{\mathrm{a}}\right) \\
16.8\left(\text { trans }, \mathrm{H}-8, \mathrm{H}-10_{\mathrm{b}}\right) \\
9.6(\mathrm{H}-8, \mathrm{H}-9)\end{array}$ & $5.77, \mathrm{~m}$ \\
\hline 9 & $\begin{array}{l}2.58, \text { ddd, } 5.1,9.2, \\
15.0\end{array}$ & $2.86, \mathrm{~m}$ & $2.92, \mathrm{~d}, 9.6$ & $\begin{array}{l}\text { 2.68, ddd, } 8.7, \\
5.5,5.0\end{array}$ \\
\hline 10 & $5.14,2 \mathrm{H}, \mathrm{m}$ & $5.22,2 \mathrm{H}, \mathrm{m}$ & $\begin{array}{l}5.38, \mathrm{~d}, 9.2\left(\text { cis, } \mathrm{H}-10_{\mathrm{a}}, \mathrm{H}-8\right) \\
16.8\left(\text { trans }, \mathrm{H}-10_{\mathrm{b}}, \mathrm{H}-8\right)\end{array}$ & $5.29, \mathrm{~m}$ \\
\hline 11- $\mathrm{COOCH}_{3}$ & - & - & $3.31,3 \mathrm{H}, \mathrm{s}$ & $3.71,3 \mathrm{H}, \mathrm{s}$ \\
\hline $12 \mathrm{a}$ & - & - & - & $3.31,3 \mathrm{H}, \mathrm{s}$ \\
\hline $12 b$ & - & - & - & $3.31,3 \mathrm{H}, \mathrm{s}$ \\
\hline $1^{\prime}$ & $4.61, d, 7.2$ & $4.51, \mathrm{~d}, 7.2$ & $4.60, d, 7.9$ & $4.68, d, 7.7$ \\
\hline 21 & $3.25, \mathrm{~m}$ & $3.41, \mathrm{~m}$ & $3.13-3.18, \mathrm{~m}$ & $3.36, \mathrm{~m}$ \\
\hline $\mathbf{3}^{\prime}$ & $3.29, \mathrm{~m}$ & $3.25, \mathrm{~m}$ & $3.13-3.18, \mathrm{~m}$ & $3.21, \mathrm{~m}$ \\
\hline $4^{\prime}$ & $3.41, \mathrm{~m}$ & $3.26, \mathrm{~m}$ & $3.13-3.18, \mathrm{~m}$ & $3.24, \mathrm{~m}$ \\
\hline 51 & $3.41, \mathrm{~m}$ & $3.30, \mathrm{~m}$ & $3.13-3.18, \mathrm{~m}$ & $3.92, \mathrm{~m}$ \\
\hline $66^{\prime}$ & $\begin{array}{l}6_{a}: 4.05, \mathrm{dd}, 4.5,11.6 \\
6_{b}: 4.52, \mathrm{~d}, 11.6\end{array}$ & $\begin{array}{l}6_{\mathrm{a}}: 3.65, \mathrm{dd}, 4.5,11.6 \\
6_{\mathrm{b}}: 3.75, \mathrm{~d}, 11.6\end{array}$ & $\begin{array}{l}\text { a: } 3.85, \mathrm{dd}, 2.4,12.0 \\
\text { b: } 3.35, \mathrm{~m}\end{array}$ & $\begin{array}{l}3.92, \mathrm{~m} \\
3.66, \mathrm{~m}\end{array}$ \\
\hline
\end{tabular}


Table 2: ${ }^{13} \mathrm{C}-\mathrm{NMR}$ assignments for compounds 1-5 (Cpds. 1, 2, $\mathbf{3}$ in $\mathrm{CD}_{3} \mathrm{OD}$ and compounds 4, $\mathbf{5}$ in DMSO- $d_{6}, 100 \mathrm{MHz}$ ).

\begin{tabular}{|c|c|c|c|c|c|c|}
\hline \multirow{2}{*}{$\begin{array}{c}\text { Carbon } \\
\text { No. }\end{array}$} & \multicolumn{6}{|c|}{ "Chemical shift ${ }^{13} \mathrm{C}$ - NMR $(\delta$, mult. $)$} \\
\hline & Cpd. 1 (a) & Cpd. 1 (b) & Cpd. 2 & Cpd. 3 & Cpd. 4 & Cpd. 5 \\
\hline 1 & $98.0, \mathrm{~d}$ & $97.0, \mathrm{~d}$ & $97.4, \mathrm{~d}$ & $97.8, \mathrm{~d}$ & $162.7, \mathrm{~s}$ & $161.7, \mathrm{~s}$ \\
\hline 2 & - & - & - & - & $97.7, \mathrm{~d}$ & $97.8, \mathrm{~d}$ \\
\hline 3 & $153.8, \mathrm{~d}$ & $152.0, \mathrm{~d}$ & $153.6, \mathrm{~d}$ & $153.1, \mathrm{~d}$ & $166.9, \mathrm{~s}$ & $166.9, \mathrm{~s}$ \\
\hline 4 & $105.0, \mathrm{~s}$ & $111.0, \mathrm{~s}$ & $110.1, \mathrm{~s}$ & $111.6, \mathrm{~s}$ & $\begin{array}{c}93.0, d \\
4 a=157.6, s \\
4 b=140.7, s\end{array}$ & $\begin{array}{c}93.1, \mathrm{~d} \\
4 \mathrm{a}=154.0, \mathrm{~s} \\
4 \mathrm{~b}=145.3, \mathrm{~s}\end{array}$ \\
\hline 5 & $28.3, \mathrm{~d}$ & $28.7, \mathrm{~d}$ & $28.3, \mathrm{~d}$ & $29.3, \mathrm{~d}$ & $124.6, \mathrm{~s}$ & $124.6, \mathrm{~s}$ \\
\hline 6 & $35.4, \mathrm{t}$ & $25.9, \mathrm{t}$ & $34.9, \mathrm{t}$ & $33.1, \mathrm{t}$ & $132.5, \mathrm{~s}$ & $149.3, \mathrm{~s}$ \\
\hline 7 & $69.7, \mathrm{t}$ & $69.7, \mathrm{t}$ & $176.3, \mathrm{~s}$ & $104.3, \mathrm{~d}$ & $150.4, \mathrm{~s}$ & $147.5, \mathrm{~s}$ \\
\hline 8 & $133.2, \mathrm{~d}$ & $134.1, \mathrm{~d}$ & $134.5, \mathrm{~d}$ & $135.8, \mathrm{~d}$ & $\begin{array}{c}154.3, \mathrm{~s} \\
8 \mathrm{a}=109.0, \mathrm{~s} \\
8 \mathrm{~b}=102.2, \mathrm{~s}\end{array}$ & $\begin{array}{c}142.2, \mathrm{~s} \\
8 \mathrm{a}=112.8, \mathrm{~s} \\
8 \mathrm{~b}=103.0, \mathrm{~s}\end{array}$ \\
\hline 9 & $43.9, \mathrm{~d}$ & $44.6, \mathrm{~d}$ & $45.2, \mathrm{~d}$ & $45.2, \mathrm{~d}$ & $183.9, \mathrm{~s}$ & $183.3, \mathrm{~s}$ \\
\hline 10 & $120.7, \mathrm{t}$ & $121.0, \mathrm{t}$ & $121.3, \mathrm{t}$ & $119.8, \mathrm{t}$ & $3-\mathrm{OCH}_{3}=55.9, \mathrm{q}$ & $3-\mathrm{OCH}_{3}=56.3, \mathrm{q}$ \\
\hline 11 & $168.5, \mathrm{~s}$ & $173.8, \mathrm{~s}$ & $170.2, \mathrm{~s}$ & $169.0, \mathrm{~s}$ & $5-\mathrm{OCH}_{3}=61.2, \mathrm{q}$ & $5-\mathrm{OCH}_{3}=61.0, \mathrm{q}$ \\
\hline $\mathrm{COOCH}_{3}$ & - & - & $51.9, \mathrm{q}$ & $51.7, \mathrm{q}$ & $6-\mathrm{OCH}_{3}=62.1, \mathrm{q}$ & $6-\mathrm{OCH}_{3}=61.5, \mathrm{q}$ \\
\hline $12 \mathbf{a}$ & - & - & - & $53.9, \mathrm{q}$ & $7-\mathrm{OCH}_{3}=61.7, \mathrm{q}$ & $7-\mathrm{OCH}_{3}=61.0, \mathrm{q}$ \\
\hline $12 b$ & - & - & - & $52.5, \mathrm{q}$ & - & $8-\mathrm{OCH}_{3}=61.7, \mathrm{q}$ \\
\hline $\mathbf{1}^{\prime}$ & $99.8, \mathrm{~d}$ & $99.8, \mathrm{~d}$ & $99.9, \mathrm{~d}$ & $100.0, \mathrm{~d}$ & & \\
\hline 21 & $74.4, \mathrm{~d}$ & $74.2, \mathrm{~d}$ & $74.6, \mathrm{~d}$ & $74.5, \mathrm{~d}$ & & \\
\hline 31 & $77.5, \mathrm{~d}$ & $75.6, d$ & 77.9, d & $77.9, \mathrm{~d}$ & & \\
\hline $4^{\prime}$ & $71.0, \mathrm{~d}$ & $71.0, \mathrm{~d}$ & $71.5, \mathrm{~d}$ & $71.4, \mathrm{~d}$ & & \\
\hline $5 \prime$ & $78.2, \mathrm{~d}$ & $78.0, \mathrm{~d}$ & $78.3, \mathrm{~d}$ & $78.3, \mathrm{~d}$ & & \\
\hline $6{ }^{\prime}$ & $62.6, \mathrm{t}$ & $62.3, \mathrm{t}$ & $62.7, \mathrm{t}$ & $62.7, \mathrm{t}$ & & \\
\hline
\end{tabular}

\section{Discussion}

The biological guided fractionation of the $n$-butanol fraction of the methanolic extract of C. spicatum (L.) Fritsch aerial parts have been resulted in the isolation of five compounds including three secoiridoids (1-3) and two xanthones (4 and 5) (Fig. 1).

Investigation of ${ }^{1} \mathrm{H}-,{ }^{13} \mathrm{C}$ - and DEPT ${ }^{13} \mathrm{C}$ NMR spectra of compound $\mathbf{1}$ (Tables 1 and 2) concluded the presence of a sweroside dimer which was obvious from the presence of two acetalic protons at $\delta_{\mathrm{H}} 5.32(2 \mathrm{H}$, brs, H1-part a) and $5.32(2 \mathrm{H}$, brs, $\mathrm{H} 1$-part $\mathrm{b})$ in addition to two vinylic protons at $\delta_{\mathrm{H}} 5.14(2 \mathrm{H}, \mathrm{m}, \mathrm{H} 10$-part a) and $5.22(2 \mathrm{H}, \mathrm{m}, \mathrm{H}-10$, part b). This was confirmed from ${ }^{13} \mathrm{C}-\mathrm{NMR}$ spectrum by the appearance of signals at $\delta_{\mathrm{c}}(98.0, \mathrm{~d}, \mathrm{C}-1$, part a) and $\delta_{\mathrm{c}}(97.0, \mathrm{~d}, \mathrm{C}-1$, part b). Regarding sugar moiety, it had been found that ${ }^{1} \mathrm{H}-\mathrm{NMR}$ spectrum displayed signals at $\delta_{\mathrm{H}} 4.61(1 \mathrm{H}, \mathrm{d}$, $J=7.2 \mathrm{~Hz}, \mathrm{H} 1^{\prime}-$ part a) and $4.51(1 \mathrm{H}, \mathrm{d}, J=7.2$ $\mathrm{Hz}, \mathrm{H1}$ '- part b) assignable to a couple of anomeric protons which was further indicated from ${ }^{13} \mathrm{C}$-NMR signals at $\delta_{\mathrm{c}} 99.8$ (d, C1'-part a) and 99.8 (d, C1'-part b). These data revealed the existence of a pair of separate glucopyranoside moieties attached to C-1 of both (a) and (b) parts ${ }^{11 \& 12}$. Configuration of the sugar moiety was concluded to be of $\beta$ type from the coupling constant of $\mathrm{H}-1$ ' of both parts ( $J=7.2 \mathrm{~Hz}$ of both parts). From the 2 DNMR correlations including both HMQC and HMBC experiments, in addition to the above mentioned data and upon comparison with literature data ${ }^{11-13}$, compound $\mathbf{1}$ was identified as a symmetrical secoiridoid dimer Lisianthoside which was firstly reported from the genus Centaurium.

The ${ }^{1} \mathrm{H}-\mathrm{NMR}$ spectrum of compound 2 (Table 1) showed the presence of an olefinic proton signal at $\delta_{\mathrm{H}} 7.59(1 \mathrm{H}$, brs, $\mathrm{H}-3)$ in addition to an acetal proton at $\delta_{\mathrm{H}} 5.43(1 \mathrm{H}, \mathrm{d}$, $J=4.1 \mathrm{~Hz}, \mathrm{H}-\mathrm{l})$ and a signal at $\delta_{\mathrm{H}} 5.38(2 \mathrm{H}, \mathrm{d}$, $J=9.2 \mathrm{~Hz}, \mathrm{H}-10$ ) which was indicative to a 

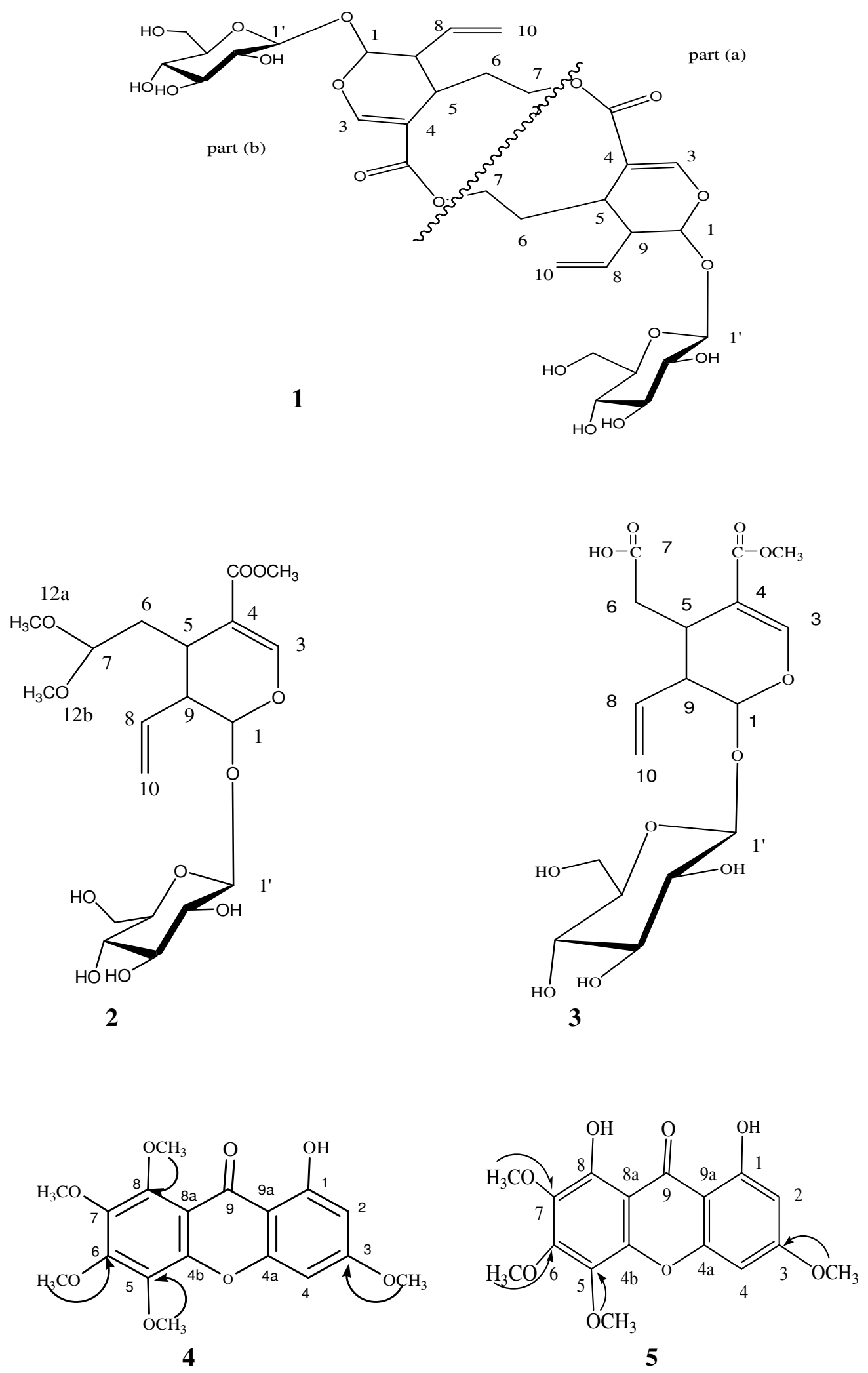

Fig. 1: Structure of compounds 1-5. 
vinylic group. A signal at $\delta_{\mathrm{H}} 2.20(1 \mathrm{H}, \mathrm{dd}, J=$ 16.8 and $9.6 \mathrm{~Hz}$ ) was assigned to the proton of C-6 exists at $\alpha$-position while the proton presents at $\beta$-position showed a signal at $\delta_{\mathrm{H}}$ $3.03(1 \mathrm{H}, \mathrm{dd}, J=16.8$ and $4.4 \mathrm{~Hz})$ and an anomeric proton signal for $\beta$ - glucopyranosyl unit appeared at $\delta_{\mathrm{H}} 4.60(1 \mathrm{H}, \mathrm{d}, J=7.9 \mathrm{~Hz}) .{ }^{13} \mathrm{C}$ NMR spectrum (Table 2) displayed 17 signals including signals which were assigned to one glucose moiety. The structure was well confirmed by HMQC and HMBC experiments and hence, compound $\mathbf{2}$ could be identified as secoxyloganin by comparison with the literature data ${ }^{14}$ which was the first report from the genus Centaurium.

The ${ }^{1} \mathrm{H}-\mathrm{NMR}$ spectrum of compound $\mathbf{3}$ (Table 1) showed the presence of an olefinic proton signal at $\delta_{\mathrm{H}} 7.44(1 \mathrm{H}, \mathrm{d}, J=3.2 \mathrm{~Hz}, \mathrm{H}-$ 3 ). Furthermore, an acetal proton signal at $\delta_{\mathrm{H}}$ $5.52(1 \mathrm{H}, \mathrm{t}, J=5.0 \mathrm{~Hz}, \mathrm{H}-1)$ and a signal for a vinyl group at $\delta_{\mathrm{H}} 5.29(2 \mathrm{H}, \mathrm{m}, \mathrm{H}-10)$. In addition, three methoxyl singlets were observed at $\delta_{\mathrm{H}} 3.71(3 \mathrm{H}, \mathrm{s}, \mathrm{H}-11), 3.31(3 \mathrm{H}, \mathrm{s}$, $\mathrm{H}-12 \mathrm{a})$ and 3.31 (3H, s, H-12b). The identification of compound $\mathbf{3}$ was well confirmed from both HMQC and HMBC experiments and it was characterized as secologanin dimethyl acetal secoiridoid ${ }^{13}$ which was first report from the genus Centaurium.

The ${ }^{1} \mathrm{H}-\mathrm{NMR}$ spectrum of compound 4 (Table 1) showed signals at $\delta_{\mathrm{H}} 11.95(1 \mathrm{H}, \mathrm{s}, 1-$ $\mathrm{OH})$ and $11.87(1 \mathrm{H}, \mathrm{s}, 8-\mathrm{OH})$, in addition to the presence of two aromatic protons at $\delta_{\mathrm{H}} 6.48$ $(1 \mathrm{H}, \mathrm{d}, J=2.4 \mathrm{~Hz}, \mathrm{H}-4)$ and $6.33(1 \mathrm{H}, \mathrm{d}, J=2.4$ $\mathrm{Hz}, \mathrm{H}-2)$. Also, the spectrum showed signals indicated the presence of four methoxy groups at $\delta_{\mathrm{H}} 4.12,3.92,3.91$ and $3.88 .{ }^{13} \mathrm{C}-\mathrm{NMR}$ spectrum (Table 2) exhibited signals characteristic to xanthone compound ${ }^{15}$. The sites of the four methoxy groups were decided to be at C-3, C-5, C-6 and C-7 from the long range $\mathrm{HMBC}$ experiment (Fig. 1). Hence, compound 4 could be identified as 1,8Dihydroxy-3,5,6,7-tetramethoxyxanthone (Demethyleustomin) ${ }^{15}$ which was first report from the genus Centaurium.

The ${ }^{1} \mathrm{H}$ - and ${ }^{13} \mathrm{C}-\mathrm{NMR}$ spectral data of compound 5 (Tables 1 and 2) were similar to those of compound $\mathbf{4}$ except for the replacement of a hydroxyl group at position $\mathrm{C}$ 8 by a methoxyl one $\left(\delta_{\mathrm{H}} 4.06\left(3 \mathrm{H}, \mathrm{s}, 8-\mathrm{OCH}_{3}\right)\right.$; $\delta_{\mathrm{c}} 61.7\left(\mathrm{q}, 8-\mathrm{OCH}_{3}\right)$. The structure was well confirmed from both HMQC and HMBC experiments (Fig. 1). Hence, compound $\mathbf{5}$ could be identified as 1-Hydroxy-3,5,6,7,8Pentamethoxyxanthone, (Eustomin) ${ }^{16}$ which was first report from the genus Centaurium.

\section{The antioxidant activity (DPPH assay)}

The antioxidant activity of the isolated compounds was measured by using DPPH radical formation assay (Table 3). In the DPPH assay, the isolated compounds 1-5 exhibited free radical scavenging activity with $\mathrm{IC}_{50}$ values of 1.37 and $1.42 \mu \mathrm{M}$ for compound 1 and compound 2 respectively, 3.62, 3.29 and $1.87 \mu \mathrm{M}$ for compounds 3-5 respectively. All tested compounds showed strong activities comparing with that of the positive control ascorbic acid $(12 \mu \mathrm{M})$.

Table 3: DPPH radical scavenging activity of compounds 1-5 from C. spicatum aerial part.

\begin{tabular}{|c|c|c|}
\hline & $\mathrm{IC}_{50}(\mu \mathrm{M})$ & \\
Compounds & 1.37 & 4 \\
\hline $\mathbf{1}$ & 1.42 & 4 \\
\hline $\mathbf{2}$ & 3.62 & 4 \\
\hline $\mathbf{3}$ & 3.29 & 4 \\
\hline $\mathbf{4}$ & 1.87 & 4 \\
\hline $\mathbf{5}$ & 12.0 & 4 \\
\hline Ascorbic acid &
\end{tabular}

$\mathrm{IC}_{50}$ values were determined by regression analysis and expressed as the mean of four replicates.

\section{Hepatoprotective effect of secoiridoids (compounds 1-3) isolated Centaurium spicatum}

It is important to clarify that SGOT and SGPT levels do not reflect the function of the liver, even though they are referred commonly to as liver function tests. They only are used to detect inflammation due to injury or damage to the liver from any source. The most important transaminases identified are glutamateoxaloacetate transaminase (GOT) glutamatepyruvate transaminase (GPT). Increased levels of SGOT and SGPT are found in cases of myocardial infarction, viral hepatitis, toxic liver necrosis, cirrhosis and malignant infiltration of the liver ${ }^{17 \& 18}$. In this study, kits utilize the spectrophotometric method of 
Karmen ${ }^{19}$ where 2,4 dinitro phenyl hydrazine is used to convert both oxaloacetate and pyruvate to the corresponding 2,4-dinitrophenylhydrazine derivatives which can be measured spectrophotomerically at $555 \mathrm{~nm}$. Liver diseases remain one of the serious health problems $^{20}$. Modern medicines have little role to alleviation of hepatic diseases and the plantbased preparations which are chiefly available medicines employed for the treatment of liver disorders ${ }^{21}$. The present study was aimed to evaluate the hepatoprotective and antioxidant activity in addition to CYP450 inhibition activity of $m \mathrm{RNA}$ of some secoiridoids and xanthones isolated from Centaurium spicatum in mice within $8 \mathrm{~h}$ through intravenous dose of $1.5 \mathrm{mg} / \mathrm{kg}$ body weight and silymarin in a dose of $50 \mathrm{mg} / \mathrm{kg}$ body weight as appositive control on mice liver damage induced by Concanavalin $\mathrm{A}^{22}$ (Table 4, Fig. 2).

It is noted from (Table 4, Fig. 2) that the tested secoiridoids (compounds 1-3) have transaminases inhibitory activity with different values $(85 \%, 88 \%, 84 \%)$ for SGOT and $(94 \%$, $98 \%, 97 \%$ ) for SGPT, respectively.

\section{CYP3A4 inhibitory activity (enzymatic activity) \\ Principle of assay \\ Vivid $^{\circledR}$ CYP450 Screening Kits enable rapid measurement of interactions between}

drug candidates and cytochrome P450 enzymes using a simple "mix-and-read" fluorescent assay (Fig. 3) that is designed for highthroughput screening in multiwell plates (Fig. 3). Test compounds are analyzed by their capacity to inhibit the production of a fluorescent signal in reactions using recombinant CYP450 isozymes and specific Vivid $^{\circledR}$ CYP450 Substrates ${ }^{16-18}$. Screening Kits are designed to assess metabolism and inhibition of the predominant human P450 isozymes involved in hepatic drug metabolism: CYP1A2, CYP2B6, CYP2C9, CYP2C19, CYP2D6, CYP2E1, CYP3A4 and CYP3A5. The Vivid $^{\circledR}$ Substrates are metabolized by a specific CYP450 enzyme into products that are highly fluorescent in aqueous solutions ${ }^{23}$.

It was concluded from figure 4 that, the inhibitory activity of the different fractions $C$. spicatum aerial parts being greater than $100 \mu \mathrm{g}$, both $90 \%$ methanol and $n$-butanol fractions have a high CYP3A4 inhibition activity $(>75 \%$ and $90 \%$ with $\mathrm{IC}_{50}=64.2$ and $3.4 \mu \mathrm{g} / \mathrm{mL}$ respectively) while $n$-hexane has no apparent activity. The correlations between the concentrations and the inhibition activity was significant where $r=0.99$ and 0.95 respectively.

Table 4: Results of the transaminases inhibition activity of compounds 1-3.

\begin{tabular}{|l|c|c|}
\hline \multicolumn{1}{|c|}{ Parameters } & $\begin{array}{c}\text { SGOT } \\
\text { (IU/L) }\end{array}$ & $\begin{array}{c}\text { SGPT } \\
\text { (IU/L) }\end{array}$ \\
\hline Normal & $46.92 \pm 5.2$ & $43.52 \pm 4.25$ \\
\hline Concanavalin A control at $1.5 \mathrm{~m} / \mathrm{kg}$ bw & $428.2 \pm 2.25$ & $520.1 \pm 1.1$ \\
\hline Silymarin $(50 \mathrm{mg} / \mathrm{kg} \mathrm{bw})+$ Concanavalin A control at $1.5 \mathrm{~m} / \mathrm{kg} \mathrm{bw}$ & $57.1 \pm 3.45$ & $48.5 \pm 3.25$ \\
\hline Compound $\mathbf{1}(100 \mathrm{mg} / \mathrm{kg} \mathrm{bw})+$ Concanavalin A control at $1.5 \mathrm{mg} / \mathrm{kg} \mathrm{bw}$ & $71.5 \pm 6.24$ & $20.2 \pm 4.3$ \\
\hline Compound $\mathbf{2}(100 \mathrm{mg} / \mathrm{kg} \mathrm{bw})+$ Concanavalin A control at $1.5 \mathrm{mg} / \mathrm{kg} \mathrm{bw}$ & $60.4 \pm 5.3$ & $22.8 \pm 2.6$ \\
\hline Compound $\mathbf{3}(100 \mathrm{mg} / \mathrm{kg}$ bw) + Concanavalin A control at $1.5 \mathrm{~m} / \mathrm{kg} \mathrm{bw}$ & $53.4 \pm 1.2$ & $14.9 \pm 3.12$ \\
\hline
\end{tabular}



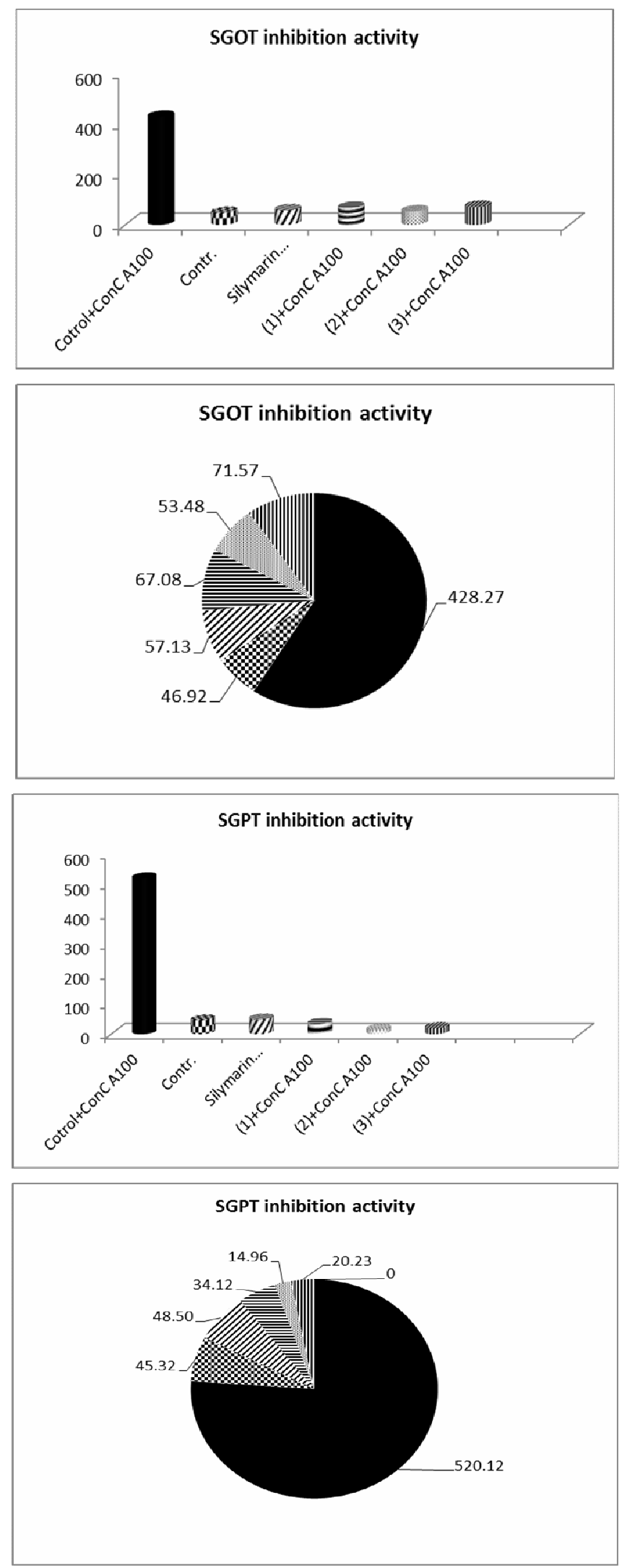

Fig. 2: Results of the transaminases inhibition activity of compounds 1-3. 


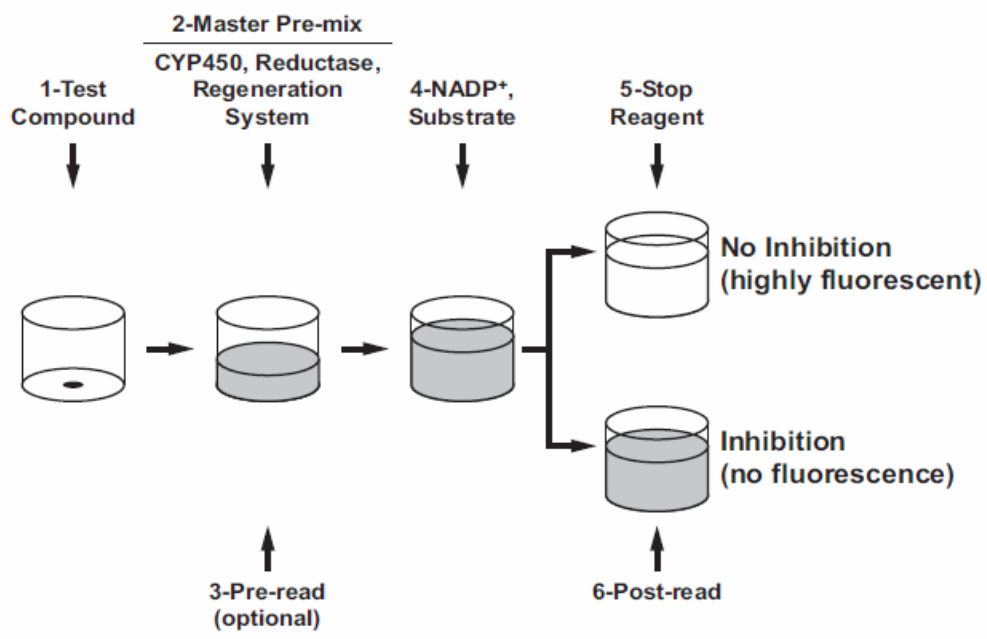

Fig. 3: Schematic representation of an endpoint $\operatorname{Vivid}^{\circledR}$ CYP3A4 assay.

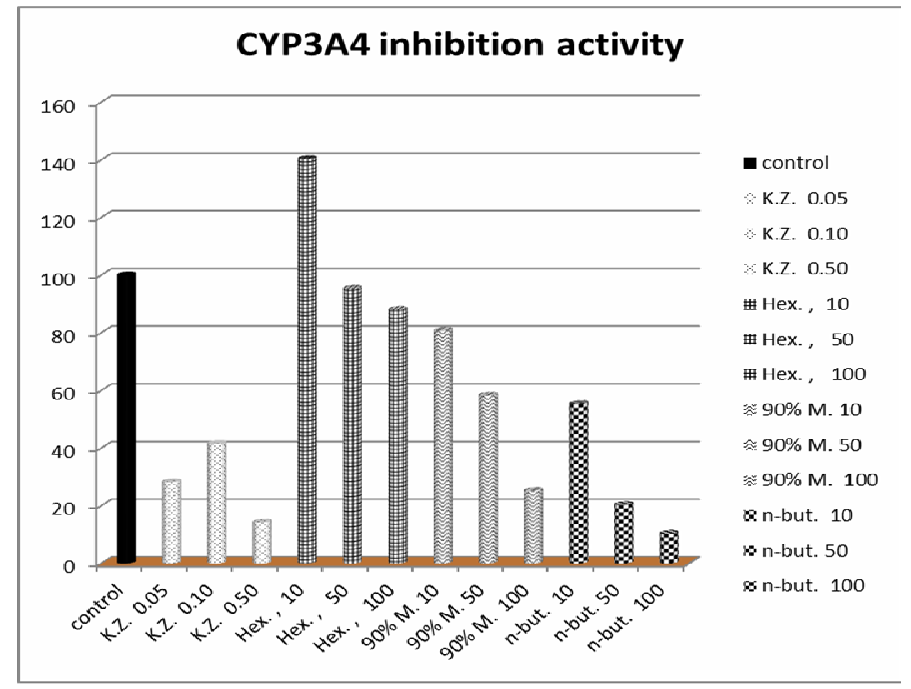

Note: K.Z. = Ketoconazole

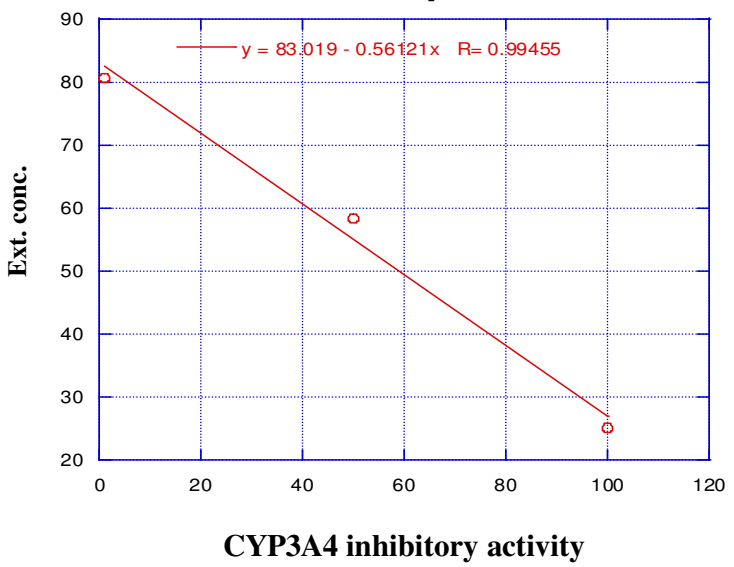

$\mathrm{IC}_{50}$ of $90 \% \mathrm{M} .=64.2 \mu \mathrm{g}$

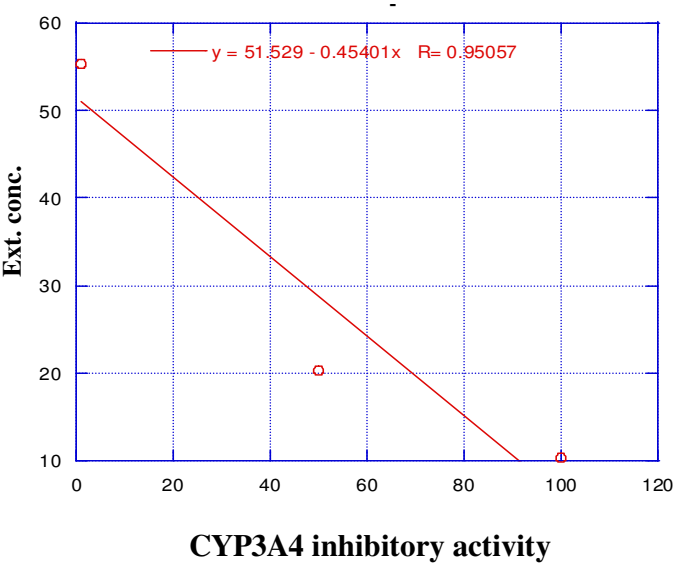

$\mathrm{IC}_{50}$ of $n$-but. $=3.4 \mu \mathrm{g}$

Fig. 4: CYP3A4 inhibition activity of $C$. spicatum of the aerial part fractions. 


\section{Acknowledgment}

This work was supported in part by Pharmacognosy and Chemistry of Natural Products, School of Pharmaceutical Sciences, Kanazawa University, Kanazawa, Japan, for which we are thankful.

\section{REFERENCES}

1- M. El-Shanawany, M. Makboul and A. Abdel Baky, "Phytochemical study of Centaurium pulchellum (SW) Druce growing in Egypt", Bull. Pharm. Sci. Assiut Univ., 12, 416-421(1989).

2- M. El-Shanawany, A. Samir, A. Gamal, M. Alaa and R. Sabrin, "A new xanthone from the roots of Centaurium spicatum L", Phytochem. Lett., 4 (2), 126-128

3- (01 Man der Sluis and R. Labadie, "Secoiridoids and xanthones in the genus Centaurium", Planta Med., 41 (3), 221231(1981).

4- D. Bishay, S. Ross and P. Hylands, "Alkaloids and glycosides from Centaurium spicatum", ibid., 37 (11), 253-258 (1979).

5- A. A. Shahat, "Isolation, Complete NMR Data and Hepatoprotective Activity of Sweroside as Major Constituents of Centaurium spicatum (L.) Growing in Egypt", $1^{\text {st }}$ International Conference of the Arab Society for Medical Research, Nov. 7-9 (2006).

6- M. V. Berridge and A. S. Tan, "Characterization of the cellular reduction of 3-(4,5-dimethylthiazol-2yl)-2,5diphenyltetrazolium bromide (MTT) Subcellular localization, substrate dependence, and involvement of mitochondrial electron transport in MTT reduction", Arch. Biochem. Biophys., 303, 474-482 (1993).

7- V. Kumar and M. Mohan, "Physicochemical status and primary productivity of Ana Sagar lake, Ajmer (Rajasthan), India", Univ. J. of Envir. Res. and Tech., 1, 286-292 (2011).

8- T. Berkan, L. Ustünes, F. Lermioglu and A. Ozer, "Antiinflammatory, analgesic and antipyretic effects of an aqueous extract of Centaurium erythraea", Planta Med., 57 (1), 34-37 (1991).
9- P. Valentão, F. Areias, J. Amaral, P. Andrade and R. Seabra, "Tetraoxygenated xanthones from Centaurium erythraea", Nat. Prod. Lett., 14, 319-323 (2000).

10- K. Javidnia, L. Dastgheib, S. Mohammadi and A. Nasiri, "Antihirsutism activity of Fennel (fruits of Foeniculum vulgare) extract". A double-blind placebo controlled study, Phytomed., 10, 455-458 (2003).

11- M. Hamburger, M. Hostettmann, H. Stoeckli, P. N. Solis, M. P. Gupta and K. Evans Hostettmann, "A novel type of dimeric secoiridoid glycoside from Lisianthius jefensis Robyns et Elias", Helv. Chim. Acta., 73 (7), 1845-1852 (1990).

12- T. Takao, T. Yukiko and N. Naotaka, "Two dimeric secoiridoid glucosides from Jasminum polyanthum", Phytochemistry, 41, 1341-1345 (1996).

13- J. Hewett and R. Roth, "Hepatic and extrahepatic pathobiology of bacterial lipopolysaccharides", Pharmacol. Rev., 45, 382-411 (1993).

14- C. Adriana, V. Robert, W. Alfons and R. Lefeber, "The iridoid glucoside secologanin is derived from the novel triose phosphate/pyruvate pathway in a Catharanthus roseus cell culture", FEBS Lett., 434, 413-416 (1998).

15- V. Valentão, B. Paula, E. Andrade and S. Eurico, "Isolation and structural elucidation of 5-formyl-2,3-dihydroisocoumarin from Centaurium erythraea aerial parts", J. Agric. Food Chem., 50 (3), 460-463 (2002).

16- T. Lamberto, M. Francesca, M. Cometa and N. Marcello, "Isolation of secoiridoid artifacts from Lonicera japonica", J. Nat. Prod., 58 (11), 1756-1758 (1995).

17- W. Watson, Y. Zhao and R. Chawla, "Sadenosylmethionine attenuates the lipopolysaccharide-induced expression of the gene for tumor necrosis factor alpha", Biochem. J., 342, 21-25 (1999).

18- P. Kubes and D. McCafferty, "Nitric oxide and intestinal inflammation", $\boldsymbol{A m}$. J. Med., 109, 150-158 (2000).

19- A. Karmen, F. blewski and J. LaDue, "Transaminase activity in human blood", J. Clin. Invest., 34, 126-131 (1955). 
20- P. Baranisrinivasan, C. Elumalai, S. Sivaakumar, T. Viviyan and E. David, "Fatty acid profile tocopherol content and total antioxidant activity of oil extracted from Nigella sativa seeds", Int. J. Pharmacol., 5, 268-272 (2009).

21- S. Raju, S. Jayalakshmi, S. Usharani and K. Sreeramulu, "Induction of systemic acquired resistance in susceptible and resistant cultivars of chickpea (Cicer arietinum L) genotypes: A comparative study in response to salicylic acid and spermine", Physiol. Mol. Biol. Plants, 13, 27-36 (2007).
22- G. Tiegs, J. Hentschel and A. Wendel, "A $\mathrm{T}$ cell-dependent experimental liver injury in mice inducible by concanavalin A", $\boldsymbol{J}$. Clin. Invest., 90 (1), 196-203 (1992).

23- L. Cohen, H. Einolf, V. Fischer, L. Gan, S. Grimm and J. Kao, "In-vitro drug interaction of cytochrome P450: An evaluation of fluorogenic to conventional substrate", Drug Metab. Dispos., 31, 1005-1015 (2003). 


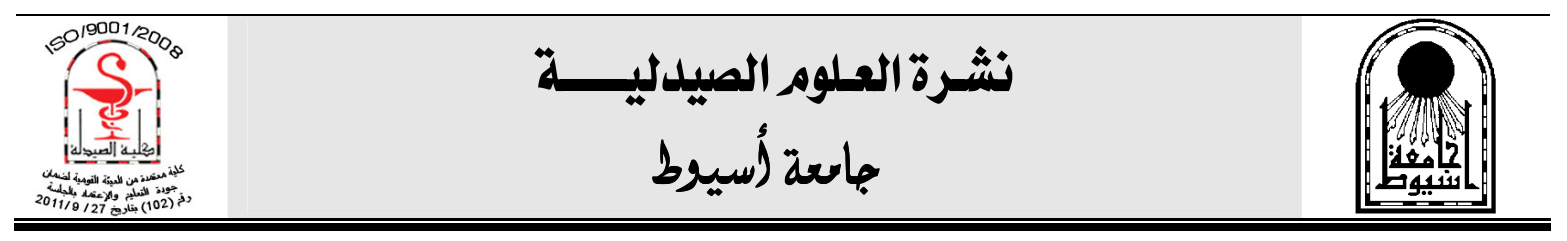

دراسة فيتوكيميائية للأجزاء العلوية لنبات السنتاوريوم ذات التأثير الواقى للكبد و والمثبطة لعمل إنزيمات العض النبات النواويوى الرسول

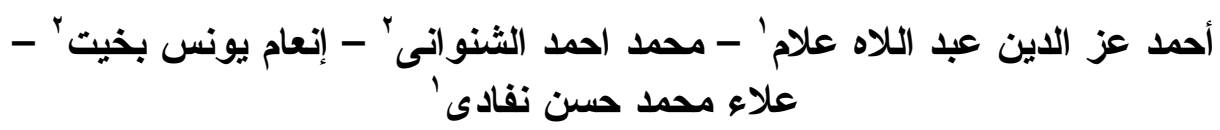

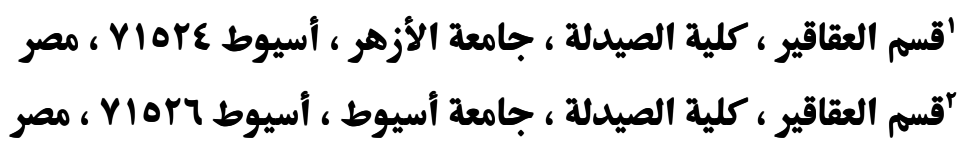

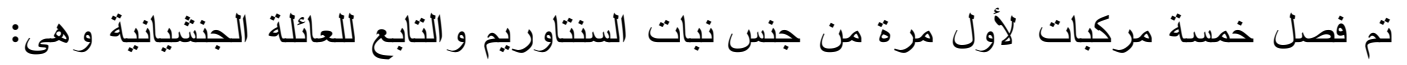

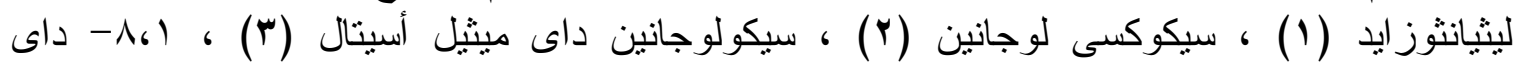

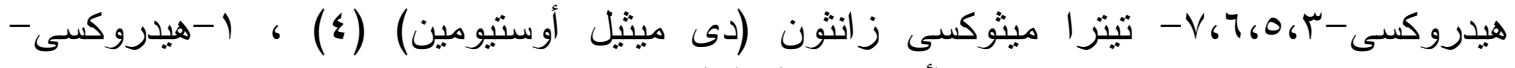


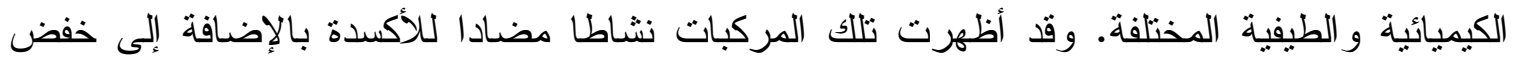

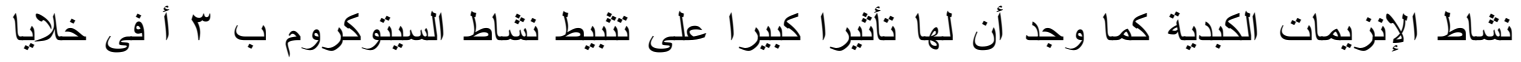

